Key Words:

Oxalic acid,

Tank Closure,

Chemical

cleaning

Retention:

Permanent

\title{
Analysis of Samples from Tank 6F Chemical Cleaning
}

\author{
Michael R. Poirier \\ Samuel D. Fink
}

February 2, 2010

Savannah River National Laboratory

Savannah River Nuclear Solutions

Aiken, SC 29808 


\section{DISCLAIMER}

This work was prepared under an agreement with and funded by the U.S. Government. Neither the U. S. Government or its employees, nor any of its contractors, subcontractors or their employees, makes any express or implied:

1. warranty or assumes any legal liability for the accuracy, completeness, or for the use or results of such use of any information, product, or process disclosed; or

2. representation that such use or results of such use would not infringe privately owned rights; or

3. endorsement or recommendation of any specifically identified commercial product, process, or service.

Any views and opinions of authors expressed in this work do not necessarily state or reflect those of the United States Government, or its contractors, or subcontractors.

Printed in the United States of America

Prepared for

U.S. Department of Energy 
Key Words:

Oxalic acid,

Tank Closure,

Chemical

cleaning

Retention:

Permanent

\title{
Analysis of Samples from Tank 6F Chemical Cleaning
}

\author{
Michael R. Poirier \\ Samuel D. Fink
}

February 2, 2010

Savannah River National Laboratory

Savannah River Nuclear Solutions

Savannah River Site

Aiken, SC 29808 


\section{REVIEWS AND APPROVALS}

\section{Authors}

M. R. Poirier, SRNL, Separations Science Programs

Date

\section{Design Check}

K. M. Taylor-Pashow, SRNL, Separations Science Programs

Date

\section{Management}

S. D. Fink, Manager, SRNL, Separations Science Programs

Date

S. L. Marra, Manager, SRNL E\&CPT Research Programs

Date

\section{Customer}

W. L. Isom, Jr., Manager, Closure Projects Engineering

Date 


\section{TABLE OF CONTENTS}

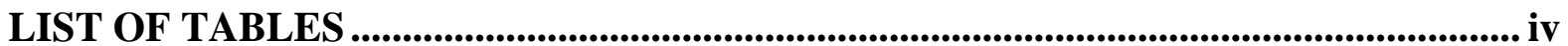

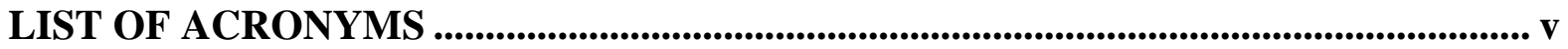

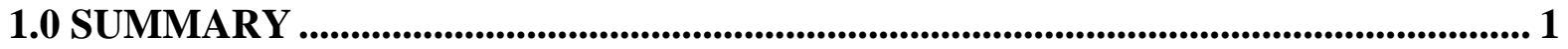

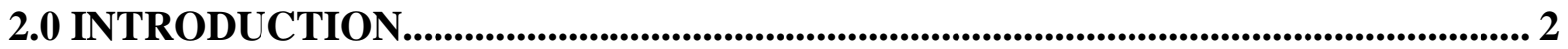

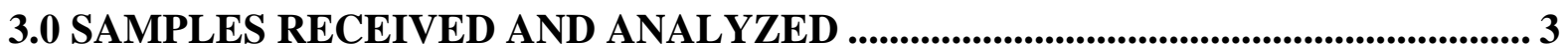

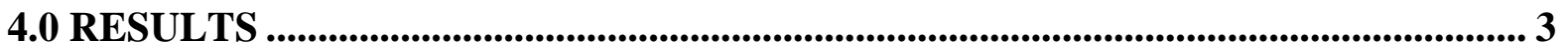

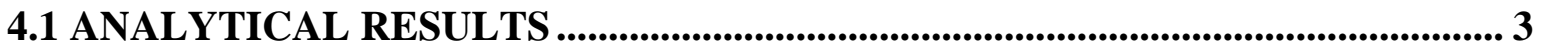

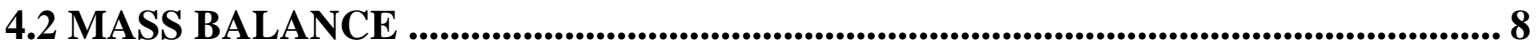

4.3 COMPARISON WITH CHEMICAL CLEANING DEMONSTRATIONS........... 12

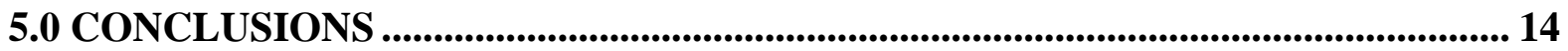

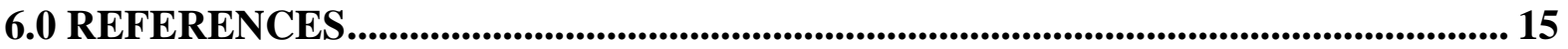




\section{LIST OF TABLES}

Table 1. Density and pH of Liquid Samples............................................................. 4

Table 2. Cation Analysis of Tank 6F Liquid Samples....................................................... 4

Table 3. Anion Analysis of Tank 6F Liquid Samples .................................................... 5

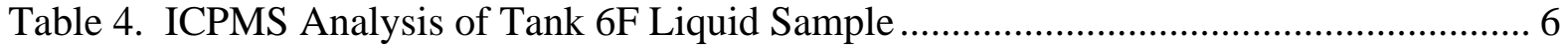

Table 5. Radionuclide Analysis of Tank 6F Liquid Samples ............................................. 6

Table 6. Cations Analysis of Tank 6F Process Sample ${ }^{\mathrm{c}}$...................................................... 7

Table 7. ICPMS Analysis of Tank 6F Process Sample ${ }^{\mathrm{a}}$..................................................... 7

Table 8. Radionuclide Analysis of Tank 6F Process Sample .............................................. 8

Table 9. Analysis of Free Liquid Collected from Process Sample ........................................ 9

Table 10. Volumes of Sludge and Liquid in Tank 6F during Chemical Cleaning ................. 9

Table 11. Amount of Material Removed from Tank 6F .................................................. 10

Table 12. Fraction Removed and Amount Remaining in Tank 6F.................................. 11

Table 13. Comparing Oxalic Acid Dissolution in Tank 5F with SRNL Demonstrations ..... 12 


\section{LIST OF ACRONYMS}

CVAA Cold Vapor Atomic Absorption Spectroscopy

IC Ion Chromatography

ICPES Inductively Coupled Plasma Emission Spectroscopy

ICPMS Inductively Coupled Plasma Mass Spectrometry

LWO Liquid Waste Organization

PuTTA Plutonium Thenoyl Trifluoroacetone Scintillation

SMP Submersible Mixer Pumps

SRNL Savannah River National Laboratory

SRR Savannah River Remediation

SRS Savannah River Site 


\subsection{SUMMARY}

The Savannah River Site (SRS) is preparing Tank 6F for closure. The first step in preparing the tank for closure is mechanical sludge removal. Following mechanical sludge removal, Savannah River Remediation (SRR) performed chemical cleaning with oxalic acid to remove the sludge heel. They are currently assessing the effectiveness of the chemical cleaning.

SRR collected liquid samples during chemical cleaning and submitted them to SRNL for analysis. Following chemical cleaning, they collected a solid sample (i.e., process sample) and submitted it to SRNL for analysis. SRNL analyzed these samples to assess the effectiveness of the chemical cleaning process.

The conclusions from this work are as follows.

- The dissolution of sludge components in Tank 6F agreed well with the expected behavior as projected from the 2007 actual waste demonstration for Tank 5F. The iron removal from Tank $6 \mathrm{~F}(70 \%)$ agrees better with the demonstration results (62\%) than the iron removal from Tank $5 \mathrm{~F}(30 \%){ }^{\mathrm{i}}$

- The chemical cleaning removed more than $95 \%$ of the uranium isotopes.

- The chemical cleaning removed $~ 73 \%$ of the neptunium, $\sim 87 \%$ of the ${ }^{90} \mathrm{Sr}$, and $\sim 87 \%$ of the ${ }^{137} \mathrm{Cs}$.

- The chemical cleaning removed less than $15 \%$ of the technetium, plutonium, americium, and curium isotopes.

- Most of the activity remaining in the tank is from beta emitters and ${ }^{90} \mathrm{Sr}$.

- The chemical cleaning removed more than $90 \%$ of the aluminum, calcium, sodium, and uranium from the tank.

- The fraction of chromium, iron, lithium, magnesium, manganese, silicon, and zirconium removed was $50-90 \%$.

- The fraction of barium removed was $20 \%$.

- Only $2 \%$ of the nickel was removed.

- Most of the mass remaining in the tank is iron and nickel.

- The remaining sludge contains $\sim 21 \mathrm{~kg}$ of barium, $\sim 4 \mathrm{~kg}$ of chromium, and $\sim 93 \mathrm{~kg}$ of mercury.

- Chemical cleaning in Tank 6F showed better removal of iron, plutonium, americium, and curium than in Tank 5F. The likely causes of the better removal are the lower $\mathrm{pH}$ following Acid Strike 1 and different chemical compounds in Tank 6F than in Tank 5F.

SRNL makes the following recommendations to remove the remaining sludge and activity in Tank 6F and to improve sludge heel removal in other tanks.

\footnotetext{
${ }^{\mathrm{i}}$ Note that the values cited in this report are based on a single sample of the liquid during each oxalic cleaning and water wash phase and solids samples from a single location following the water wash. Therefore, relatively large variability may be associated with the specific values. However, the reported values are useful for understanding the effect of chemical cleaning in Tank 6F and for deriving general conclusions.
} 
- When performing chemical cleaning on future waste tanks, ensure the $\mathrm{pH}$ of the acid is less than 2 before removing the acid from the tank. The lower $\mathrm{pH}$ will increase iron solubility.

- Prior to performing chemical cleaning for future tanks, collect a sludge sample and have it analyzed for key contaminants. This provides a baseline for comparison, which allows a better evaluation of the efficiency of future chemical cleaning activities.

- Future work should include analysis of the solid samples by a method such as X-ray diffraction (XRD) to identify the specific compounds of the key contaminants.

- Mix the tank as soon as it contains sufficient liquid. The mixing will promote contact between the acid and sludge, improving the dissolution rate. The mixing will also suspend particles not dissolved by the acid.

- The sludge heel should be washed to reduce the liquid ionic strength prior to starting chemical cleaning. Reducing the ionic strength will increase the oxalate solubility.

\subsection{INTRODUCTION}

SRR is preparing Tank 6F for closure. The first step in preparing the tank for closure is mechanical sludge removal. In mechanical sludge removal, personnel add liquid (e.g., inhibited water or supernate salt solution) to the tank to form a slurry. They mix the liquid and sludge with pumps, and transfer the slurry to another tank for further processing.

Mechanical sludge removal effectively removes the bulk of the sludge from a tank, but is not able to remove all of the sludge. In Tank 6F, SRR estimated a sludge heel of 5,984 gallons remained after mechanical sludge removal. ${ }^{1}$ To remove this sludge heel, SRR performed chemical cleaning. The chemical cleaning included two oxalic acid strikes, a spray wash, and a water wash.

SRR conducted the first oxalic acid strike as follows. Personnel added 110,830 gallons of $8 \mathrm{wt} \%$ oxalic acid to Tank $6 \mathrm{~F}$ and mixed the contents of Tank 6F with two submersible mixer pumps (SMPs) for approximately four days. Following the mixing, they transferred 115,903 gallons of Tank 6F material to Tank 7F. The SMPs were operating when the transfer started and were shut down approximately five hours after the transfer started. SRR collected a sample of the liquid from Tank 6F and submitted it to SRNL for analysis. ${ }^{2}$ Mapping of the tank following the transfer indicated that 2,400 gallons of solids remained in the tank.

SRR conducted the second oxalic acid strike as follows. Personnel added 28,881 gallons of $8 \mathrm{wt} \%$ oxalic acid to Tank 6F. Following the acid addition, they visually inspected the tank and transferred 32,247 gallons of Tank 6F material to Tank 7F. ${ }^{3}$ SRR collected a sample of the liquid from Tank 6F and submitted it to SRNL for analysis. ${ }^{2}$ Mapping of the tank following the transfer indicated that 3,248 gallons of solids remained in the tank.

Following the oxalic acid strikes, SRR performed Spray Washing with oxalic acid to remove waste collected on internal structures, cooling coils, tank top internals, and tank walls. The Acid Spray Wash was followed by a Water Spray Wash to remove oxalic acid from the tank internals. SRR conducted the Spray Wash as follows. Personnel added 4,802 gallons of $8 \mathrm{wt} \%$ oxalic acid to Tank 6F through the spray mast installed in Riser 2, added 4,875gallons of oxalic acid through 
Riser 7, added 5,000 gallons of deionized water into the tank via Riser 2, and 5,000 gallons of deionized water into the tank via Riser 7. Following the Spray Wash, they visually inspected the tank and transferred 22,430 gallons of Tank 6F material to Tank 7F. ${ }^{4}$ SRR collected a sample of the liquid from Tank $6 \mathrm{~F}$ and submitted it to SRNL for analysis. ${ }^{2}$

Following the Spray Wash and transfer, SRS added 113,935 gallons of well water to Tank 6F. They mixed the tank contents with a single SMP and transferred 112,699 gallons from Tank 6F to Tank 7F. ${ }^{4}$ SRR collected a sample of the liquid from Tank 6F and submitted to SRNL for analysis. ${ }^{2}$ Mapping of the tank following the transfer indicated that 3,488 gallons of solids remained in the tank.

Following the Water Wash, SRR personnel collected a solid sample and submitted it to SRNL for analysis to assess the effectiveness of the chemical cleaning and to provide a preliminary indication of the composition of the material remaining in the tank.

\subsection{SAMPLES RECEIVED AND ANALYZED}

SRNL received liquid samples following oxalic acid Strike 1, oxalic acid Strike 2, the Spray Wash, and the Water Wash. They analyzed the samples for $\mathrm{pH}$ by $\mathrm{pH}$ paper, for density gravimetrically, and for turbidity. ${ }^{2}$ Following these analyses, they filtered subsamples, diluted them to reduce the dose, and analyzed them for cations (ICPES), anions (IC), and radionuclides (ICPMS, liquid scintillation counting, gamma scan, PuTTA, Sr-90, Tc-99, and Am/Cm methods).

SRNL received three solid samples from Tank 6F. SRNL collected two subsamples from each sample. They digested one of the subsamples by the aqua regia method and the other by the peroxide fusion method. They analyzed them for cations (ICPES), anions (IC), mercury (CVAA), and radionuclides (ICPMS, liquid scintillation counting, gamma scan, PuTTA, Sr-90, Tc-99, and Am/Cm methods).

SRNL collected a small amount of free liquid from one of the solid samples ( $1 \mathrm{~g})$, filtered it, diluted it with water, and analyzed the sample for mercury (CVAA), anions (IC), and radionuclides (ICPMS, liquid scintillation counting, gamma scan, PuTTA, Sr-90, Tc-99, and Am/Cm methods).

\subsection{RESULTS}

\subsection{ANALYTICAL RESULTS}

Table 1 shows the measured $\mathrm{pH}$ and density of the liquid samples following the oxalic acid strikes, the Spray Wash, and the Water Wash in Tank 6F. The $\mathrm{pH}$ following Strike 1 is 2, which agrees with the measured $\mathrm{pH}$ following acid addition in the Tank $5 \mathrm{~F}$ demonstrations $(\mathrm{pH}=1-$ 2). ${ }^{5,6}$ The $\mathrm{pH}$ following Strike 1 is lower than the $\mathrm{pH}$ following Strike 1 in Tank 5F, which should lead to better sludge removal. ${ }^{7}$ 
Table 1. Density and pH of Liquid Samples

\begin{tabular}{lllll} 
Analysis & Strike 1 & Strike 2 & Spray Wash & Water Wash \\
\cline { 2 - 5 } & 2 & 2 & 3 & 7 \\
Density $(\mathrm{g} / \mathrm{mL})$ & $1.100 \pm 0.005$ & $1.035 \pm 0.007$ & $0.996 \pm 0.003$ & $1.051 \pm 0.001$
\end{tabular}

Table 2, Table 3, Table 4, and Table 5 show the measured composition of liquid samples collected during chemical cleaning. Table 2 shows the cation concentrations in the samples. The data show a significant decrease in the concentration of the major cations (i.e., $\mathrm{Al}, \mathrm{Ca}, \mathrm{Fe}$, $\mathrm{Mn}, \mathrm{Na}, \mathrm{Si}$, and $\mathrm{U}$ ) in Strike 2 compared to Strike 1. The likely cause of this result is the dissolution and removal of the cations during Strike 1. Comparing the composition of the liquid following the Spray Wash with the liquid following the second acid strike shows approximately the same concentration of all of the major cations. The concentration of the major species is significantly lower in the Water Wash sample than in the Spray Wash sample. This result is likely due to the removal of the metals in the acid strikes and Spray Wash and to the higher $\mathrm{pH}$ during the water wash.

\begin{tabular}{|c|c|c|c|c|}
\hline Species & Strike 1 (mg/L) & Strike 2 (mg/L) & Spray Wash & Water Wash(mg/L) \\
\hline$\overline{\mathrm{Al}}$ & $1031 \pm 103$ & $185 \pm 18$ & $\overline{176 \pm 18}$ & $21.4 \pm 2.1$ \\
\hline $\mathrm{Ba}$ & $11 \pm 1.1$ & $5.1 \pm 0.5$ & $3.0 \pm 0.3$ & $<3.8$ \\
\hline $\mathrm{Ca}$ & $270 \pm 27$ & $59 \pm 5.9$ & $33 \pm 3.3$ & $4.49 \pm 0.45$ \\
\hline $\mathrm{Cr}$ & $16 \pm 1.6$ & $4.6 \pm 0.46$ & $4.6 \pm 0.5$ & $<3.66$ \\
\hline $\mathrm{Fe}$ & $11745 \pm 1175$ & $2450 \pm 245$ & $2864 \pm 286$ & $210 \pm 21$ \\
\hline K & $21 \pm 2.1$ & $<15$ & $<11$ & $<16.7$ \\
\hline $\mathrm{La}$ & $15 \pm 1.5$ & $<2.9$ & $<2.1$ & $<0.813$ \\
\hline $\mathrm{Li}$ & $68 \pm 6.8$ & $16.8 \pm 1.7$ & $11.6 \pm 1.2$ & $<3.20$ \\
\hline $\mathrm{Mg}$ & $34 \pm 3.4$ & $9.1 \pm 0.9$ & $9.5 \pm 1.0$ & $1.69 \pm 0.17$ \\
\hline $\mathrm{Mn}$ & $593 \pm 59$ & $100 \pm 10$ & $85 \pm 8.5$ & $25.1 \pm 2.5$ \\
\hline $\mathrm{Na}$ & $3000 \pm 300$ & $918 \pm 92$ & $804 \pm 80$ & $644 \pm 64$ \\
\hline $\mathrm{Ni}$ & $50 \pm 5$ & $7.6 \pm 0.76$ & $5.8 \pm 0.6$ & $<6.16$ \\
\hline $\mathrm{P}$ & $60 \pm 6$ & $11.6 \pm 1.2$ & $<21$ & $<14.7$ \\
\hline $\mathrm{Pb}$ & $18 \pm 1.8$ & $6.9 \pm 0.7$ & $7.6 \pm 0.8$ & $<9.28$ \\
\hline $\mathrm{S}$ & $79 \pm 7.9$ & $88 \pm 8.8$ & $<621$ & $<182$ \\
\hline Si & $271 \pm 27$ & $41 \pm 4.1$ & $27 \pm 2.7$ & $36.7 \pm 3.7$ \\
\hline $\mathrm{Sr}$ & $34 \pm 3.4$ & $6.1 \pm 0.61$ & $4.1 \pm 0.4$ & $<0.73$ \\
\hline $\mathrm{Ti}$ & $9.5 \pm 0.95$ & $2.3 \pm 0.23$ & $4.4 \pm 0.4$ & $<0.816$ \\
\hline $\mathrm{U}$ & $4943 \pm 494$ & $1231 \pm 123$ & $1426 \pm 143$ & $887 \pm 89$ \\
\hline $\mathrm{Zn}$ & $3 \pm 0.3$ & $<2.2$ & $<1.1$ & $<0.719$ \\
\hline $\mathrm{Zr}$ & $200 \pm 20$ & $27.3 \pm 2.7$ & $22.6 \pm 2.3$ & $1.9 \pm 0.2$ \\
\hline
\end{tabular}

The iron measured in the samples could be from sludge dissolution or from carbon steel corrosion. The average measured corrosion rate in the simulant demonstration conducted at $50{ }^{\circ} \mathrm{C}$ was $21 \mathrm{mils} / \mathrm{y}(0.021 \mathrm{in} / \mathrm{y}) .{ }^{5}$ Given a tank liquid volume of 442,000 L (46 inches), the carbon steel surface area exposed to acid is $11,770 \mathrm{ft}^{2}{ }^{8}$. Assuming the carbon steel has a density of $7.8 \mathrm{~g} / \mathrm{mL}$ and contains $99 \%$ iron $^{9}$, the amount of iron that would dissolve from corrosion in one week is calculated with equation [1].

$$
\begin{aligned}
& (0.021 \mathrm{in} / \mathrm{y})(1 \mathrm{y} / 52 \mathrm{wk})(1 \mathrm{wk})\left(11,770 \mathrm{ft}^{2}\right)(12 \mathrm{in} / \mathrm{ft})^{2}=680 \mathrm{in}^{3} \\
& 680 \mathrm{in}^{3}(2.54 \mathrm{~cm} / \mathrm{in})^{3}\left(1 \mathrm{~L} / 1000 \mathrm{~cm}^{3}\right)=11 \mathrm{~L}
\end{aligned}
$$


$11 \mathrm{~L}(7.8 \mathrm{~kg} / \mathrm{L})(0.99)=85 \mathrm{~kg}$ of iron from corrosion

$85 \mathrm{~kg} / 442,000 \mathrm{~L}\left(10^{6} \mathrm{mg} / \mathrm{kg}\right)=192 \mathrm{mg}$ Fe/L from corrosion

The concentration of iron that could be in the sample from corrosion is significantly less than the amount measured in the samples following Strike 1, Strike 2, and the Spray Wash. The measured iron concentration in the Water Wash sample is approximately the same as the concentration calculated in equation [1], but the $\mathrm{pH}$ of the Water Wash sample (7) would reduce the corrosion rate.

Table 3 shows the anion concentration in the samples. All of the anions are below the detection limit, except for oxalate. The table includes the expected oxalate concentration based on the volume and concentration of oxalic acid added to the tank. The measured concentration is significantly less following Strike 1, Strike 2, and the Spray Wash.

One possible explanation for this difference is the oxalate forming a precipitate with iron, as observed in the Tank 5F chemical cleaning demonstration. ${ }^{5}$ In that test, researchers observed $\mathrm{FeC}_{2} \mathrm{O}_{4} * \mathrm{H}_{2} \mathrm{O}$ precipitate. Analysis of Tank $6 \mathrm{~F}$ solid samples by XRD showed the dominant compounds in the solid to be hematite, maghemite, nickel oxalate hydrate, and goethite. Hematite and maghemite are iron oxides, and goethite is an iron oxyhydroxide. Therefore, iron oxalate hydrate is not likely to be the cause of the "missing oxalate". The oxalate may have precipitated with the nickel present in Tank 6F. Work by Garcia-Clavel et al. showed the reaction of nickel compounds with oxalic acid formed $\mathrm{NiC}_{2} \mathrm{O}_{4} * 2 \mathrm{H}_{2} \mathrm{O} .{ }^{10}$ XRD analysis of this sample confirmed the presence of nickel oxalate hydrate. ${ }^{11}$

\section{Table 3. Anion Analysis of Tank 6F Liquid Samples}

\begin{tabular}{|c|c|c|c|c|}
\hline Species & Strike 1 (mg/L) & Strike $2(\mathrm{mg} / \mathrm{L})$ & Spray Wash (mg/L) & Water Wash (mg/L \\
\hline $\mathrm{F}^{-}$ & $<702$ & $<325$ & $<328$ & $<334$ \\
\hline Formate & $<702$ & $<325$ & $<328$ & $<334$ \\
\hline $\mathrm{Cl}^{-}$ & $<702$ & $<325$ & $<328$ & $<334$ \\
\hline $\mathrm{NO}_{2}^{-}$ & $<702$ & $<325$ & $<328$ & $<334$ \\
\hline $\mathrm{NO}_{3}^{-}$ & $<702$ & $<325$ & $<328$ & $<334$ \\
\hline $\mathrm{PO}_{4}{ }^{2-}$ & $<702$ & $<325$ & $<328$ & $<334$ \\
\hline $\mathrm{SO}_{4}^{2-}$ & $<702$ & $<325$ & $<328$ & $<334$ \\
\hline Oxalate & $44,363 \pm 4,436$ & $51,000 \pm 5100$ & $24,600 \pm 2460$ & $1884 \pm 188$ \\
\hline $\mathrm{Br}^{-}$ & $<702$ & $<325$ & $<328$ & $<331$ \\
\hline $\begin{array}{l}\text { Oxalate } \\
\text { expected }\end{array}$ & 79,200 & 79,200 & 42,200 & 1,760 \\
\hline
\end{tabular}

Table 4 shows the radionuclides measured by ICP-MS. The uranium concentration shows good agreement with the concentration measured by ICP-ES.

Table 5 shows the radionuclide concentrations in the samples. The largest contributors to radioactivity are ${ }^{90} \mathrm{Sr}$ (and beta) and ${ }^{137} \mathrm{Cs}$. All other radionuclides are at least an order of magnitude lower. The concentrations of ${ }^{90} \mathrm{Sr}$ and ${ }^{137} \mathrm{Cs}$ in the Strike 2 sample are $1 / 3-1 / 5$ of the concentrations in the Strike 1 sample. The concentrations in the Spray Wash sample are half of their value in the Strike 2 sample. The concentrations in the Water Wash sample show an additional decrease. The beta radioactivity in the Strike 1 sample is less than the ${ }^{90} \mathrm{Sr}$ activity. 
${ }^{90} \mathrm{Sr}$ decays to ${ }^{90} \mathrm{Y}$ with a half-life of 28.78 years, and ${ }^{90} \mathrm{Y}$ decays with a half-life of 3 days. Since ${ }^{90} \mathrm{Sr}$ has a much longer half-life than ${ }^{90} \mathrm{Y}$, after several ${ }^{90} \mathrm{Y}$ half-lives, their concentrations will be the same. Therefore, the beta activity should be at least twice the ${ }^{90} \mathrm{Sr}$ activity. Discussions with the radiochemists who performed the analysis suggest this result could be due to solid particles in the sample. The samples were filtered, and a simple calculation shows a single ${ }^{90} \mathrm{Sr}$ particle with radius of $110 \mu$ or $1000{ }^{90} \mathrm{Sr}$ particles with radius of $11 \mu$ would be needed to explain the high ${ }^{90} \mathrm{Sr}$ concentration measured. We are uncertain of the reason for this discrepancy. The beta radioactivity is approximately twice the ${ }^{90} \mathrm{Sr}$ activity in the samples from Strike 2, the Spray Wash, and the Water Wash.

Table 4. ICPMS Analysis of Tank 6F Liquid Sample

\begin{tabular}{|c|c|c|c|c|}
\hline Species & $\frac{\text { Strike } 1}{\text { (mg/L) }}$ & $\frac{\text { Strike } 2}{\text { (mg/L) }}$ & $\frac{\text { Spray Wash }}{(\mathrm{mg} / \mathrm{L})}$ & $\frac{\text { Water Wash }}{(\mathrm{mg} / \mathrm{L})}$ \\
\hline${ }^{237} \mathrm{~Np}$ & $<0.7$ & $<0.48$ & $<2$ & $<0.406$ \\
\hline${ }^{239} \mathrm{Pu}$ & $0.9 \pm 0.09$ & $<0.9$ & $<1.6$ & $<0.676$ \\
\hline${ }^{234} \mathrm{U}$ & $<5$ & $<5$ & $<5$ & $<5$ \\
\hline${ }^{235} \mathrm{U}$ & $21.0 \pm 2.1$ & 5.6 & $6.8 \pm 0.7$ & $3.56 \pm 0.71$ \\
\hline${ }^{238} \mathrm{U}$ & $4776 \pm 478$ & 1132 & $1340 \pm 134$ & $905 \pm 181$ \\
\hline Total U & 4797 & $<1142$ & 1347 & $<914$ \\
\hline
\end{tabular}

Table 5. Radionuclide Analysis of Tank 6F Liquid Samples

\begin{tabular}{|c|c|c|c|c|}
\hline Species & $\underline{\text { Strike } 1(\mathrm{dpm} / \mathrm{mL})}$ & Strike $2(\mathrm{dpm} / \mathrm{mL})$ & Spray Wash (dpm/mL) & Water Wash (dpm/mL) \\
\hline${ }^{60} \mathrm{Co}$ & $<1.6 \times 10^{5}$ & $<1.6 \times 10^{5}$ & & $<7.78 \times 10^{4}$ \\
\hline${ }^{90} \mathrm{Sr}$ & $2.3 \times 10^{9} \pm 2.4 \times 10^{8}$ & $5.6 \times 10^{8} \pm 3.9 \times 10^{7}$ & $3.3 \times 10^{8} \pm 2.6 \times 10^{7}$ & $2.05 \times 10^{7} \pm 4.11 \times 10^{4}$ \\
\hline${ }^{99} \mathrm{Tc}$ & $<2.5 \times 10^{3}$ & $2.0 \times 10^{2} \pm 4.6 \times 10^{1}$ & $4.0 \times 10^{2} \pm 7.6 \times 10^{1}$ & $<4.23 \times 10^{2}$ \\
\hline${ }^{137} \mathrm{Cs}-$ & $5.5 \times 10^{7} \pm 7.3 \times 10^{5}$ & $1.6 \times 10^{7} \pm 2.8 \times 10^{5}$ & $9.9 \times 10^{6} \pm 5.0 \times 10^{5}$ & $4.31 \times 10^{6} \pm 2.15 \times 10^{3}$ \\
\hline Alpha & $<4.7 \times 10^{7}$ & $<4.6 \times 10^{6}$ & $<5.5 \times 10^{5}$ & $<3.28 \times 10^{5}$ \\
\hline Nonvolatile beta & $1.7 \times 10^{9} \pm 1.7 \times 10^{7}$ & $1.2 \times 10^{9} \pm 1.2 \times 10^{8}$ & $6.9 \times 10^{8} \pm 6.9 \times 10^{7}$ & $6.33 \times 10^{7} \pm 6.33 \times 10^{4}$ \\
\hline${ }^{226} \mathrm{Ra}$ & $<8.0 \times 10^{6}$ & & & \\
\hline${ }^{238} \mathrm{Pu}$ & $1.1 \times 10^{5} \pm 7.6 \times 10^{3}$ & $1.1 \times 10^{4} \pm 1.6 \times 10^{3}$ & $1.1 \times 10^{4} \pm 1.5 \times 10^{3}$ & $2.73 \times 10^{3} \pm 1.46 \times 10^{2}$ \\
\hline${ }^{239 / 240} \mathrm{Pu}$ & $1.4 \times 10^{5} \pm 9.9 \times 10^{3}$ & $1.8 \times 10^{4} \pm 1.9 \times 10^{3}$ & $1.5 \times 10^{4} \pm 1.8 \times 10^{3}$ & $3.53 \times 10^{3} \pm 1.80 \times 10^{2}$ \\
\hline${ }^{241} \mathrm{Am}$ & $1.2 \times 10^{6} \pm 1.9 \times 10^{5}$ & $<1.5 \times 10^{5}$ & $<2.2 \times 10^{4}$ & $5.58 \times 10^{3} \pm 9.44 \times 10^{2}$ \\
\hline${ }^{243} \mathrm{Am}$ & $2.1 \times 10^{4} \pm 4.4 \times 10^{3}$ & $<2.1 \times 10^{5}$ & $<9.6 \times 10^{3}$ & $<84.7$ \\
\hline${ }^{242 m} \mathrm{Am}$ & $2.1 \times 10^{3} \pm 6.1 \times 10^{2}$ & $<6.4 \times 10^{3}$ & $<3.5 \times 10^{2}$ & $<18.0$ \\
\hline${ }^{243} \mathrm{Cm}$ & $<1.6 \times 10^{4}$ & $<6.7 \times 10^{5}$ & $<3.2 \times 10^{4}$ & $<2.46 \times 10^{2}$ \\
\hline${ }^{245} \mathrm{Cm}$ & $<1.6 \times 10^{4}$ & $<5.5 \times 10^{5}$ & $<2.6 \times 10^{4}$ & $<3.13 \times 10^{2}$ \\
\hline${ }^{247} \mathrm{Cm}$ & $<7.0 \times 10^{3}$ & $<1.2 \times 10^{6}$ & $<4.5 \times 10^{4}$ & $<3.13 \times 10^{2}$ \\
\hline${ }^{249} \mathrm{Cf}$ & $<7.2 \times 10^{3}$ & $<1.3 \times 10^{6}$ & $<4.8 \times 10^{4}$ & $<3.49 \times 10^{2}$ \\
\hline${ }^{251} \mathrm{Cf}$ & $<4.1 \times 10^{3}$ & $<6.6 \times 10^{5}$ & $<2.9 \times 10^{4}$ & $<2.34 \times 10^{2}$ \\
\hline${ }^{242} \mathrm{Cm}$ & $1.7 \times 10^{3} \pm 4.7 \times 10^{2}$ & $<5.3 \times 10^{3}$ & $<2.9 \times 10^{2}$ & $<14.9$ \\
\hline${ }^{244} \mathrm{Cm}$ & $1.2 \times 10^{6} \pm 1.7 \times 10^{2}$ & $<1.7 \times 10^{5}$ & $7.2 \times 10^{3} \pm 2.1 \times 10^{3}$ & $9.51 \times 10^{2} \pm 2.69 \times 10^{2}$ \\
\hline
\end{tabular}

Species not detected

The process sample contained approximately $70 \mathrm{wt} \%$ solids. Table 6 shows the concentration of cations in the process sample collected following chemical cleaning in Tank 6F. The largest contributors to the sludge mass remaining in Tank $6 \mathrm{~F}$ are iron and nickel.

Table 7 shows the concentration of select uranium, neptunium, and plutonium isotopes measured by ICP-MS. The sum of the concentrations of the uranium isotopes $(2728 \mathrm{mg} / \mathrm{kg}$ by Aqua Regia and $1738 \mathrm{mg} / \mathrm{kg}$ by peroxide fusion) is consistent with the uranium concentration measured by ICP-ES ( $<2470 \mathrm{mg} / \mathrm{kg}$ by Aqua Regia and $<2507 \mathrm{mg} / \mathrm{kg}$ by peroxide fusion). 
Table 6. Cations Analysis of Tank 6F Process Sample ${ }^{c}$

\begin{tabular}{|c|c|c|c|c|}
\hline \multirow[b]{2}{*}{ Species } & \multicolumn{2}{|c|}{ Aqua Regia } & \multicolumn{2}{|c|}{ Peroxide Fusion } \\
\hline & $\begin{array}{l}\text { Sample } \\
\mathrm{mg} / \mathrm{kg}\end{array}$ & $\begin{array}{c}\text { AD Blank } \\
\mathrm{mg} / \mathrm{kg}\end{array}$ & $\begin{array}{l}\text { Sample } \\
\mathrm{mg} / \mathrm{kg}\end{array}$ & $\begin{array}{c}\text { AD Blank } \\
\mathrm{mg} / \mathrm{kg}\end{array}$ \\
\hline Al & 3300 & $<298$ & 3980 & $<862$ \\
\hline $\mathrm{Ba}$ & 1860 & $<24$ & 1338 & $<29$ \\
\hline Са & 446 & 89 & b & \\
\hline $\mathrm{Cr}$ & $\mathrm{a}$ & $\mathrm{a}$ & 535 & $<431$ \\
\hline $\mathrm{Fe}$ & 166,667 & 230,000 & 121,000 & 2,900 \\
\hline $\mathrm{Li}$ & 344 & $<169$ & $<643$ & $<647$ \\
\hline Mg & 579 & $<71$ & 415 & $<22$ \\
\hline $\mathrm{Mn}$ & 23,700 & $<984$ & 16,700 & $<37$ \\
\hline $\mathrm{Na}$ & 1,820 & $<357$ & b & b \\
\hline $\mathrm{Ni}$ & 104,000 & $<115$ & 81,000 & $<138$ \\
\hline $\mathrm{Si}$ & $\mathrm{a}$ & a & 1600 & $<226$ \\
\hline $\mathrm{Sr}$ & 72 & $<4$ & 55 & $<10$ \\
\hline $\mathrm{U}$ & $<2470$ & $<2050$ & $<2507$ & $<2500$ \\
\hline $\mathrm{Zr}$ & 770 & $<28$ & $\mathrm{~b}$ & $\mathrm{~b}$ \\
\hline $\mathrm{Hg}$ & 7040 & 18.5 & b & b \\
\hline a Peroxic & er method & pecies & & \\
\hline Aqua re & thod for $\mathrm{t}$ & & & \\
\hline
\end{tabular}

Table 7. ICPMS Analysis of Tank 6F Process Sample ${ }^{a}$

\begin{tabular}{|c|c|c|c|c|}
\hline \multirow[b]{2}{*}{ Species } & \multicolumn{2}{|c|}{ Aqua Regia } & \multicolumn{2}{|c|}{ Peroxide Fusion } \\
\hline & $\begin{array}{c}\text { Sample } \\
\mathrm{mg} / \mathrm{kg}\end{array}$ & $\begin{array}{c}\text { AD Blank } \\
\mathrm{mg} / \mathrm{kg}\end{array}$ & $\begin{array}{l}\text { Sample } \\
\mathrm{mg} / \mathrm{kg}\end{array}$ & $\begin{array}{c}\text { AD Blank } \\
\text { mg } / \mathrm{kg}\end{array}$ \\
\hline${ }^{237} \mathrm{~Np}$ & 9 & $<5$ & 6 & $<5$ \\
\hline${ }^{239} \mathrm{Pu}$ & 74 & $<9$ & 49 & $<9$ \\
\hline${ }^{234} \mathrm{U}$ & $<5$ & $<5$ & $<5$ & $<5$ \\
\hline${ }^{235} \mathrm{U}$ & 10 & $<5$ & 8 & $<5$ \\
\hline${ }^{238} \mathrm{U}$ & 2713 & $<31$ & 1725 & $<31$ \\
\hline Total U & 2723 & $<41$ & 1733 & $<41$ \\
\hline
\end{tabular}

Table 8 shows the concentration of radionuclides in the process sample collected following chemical cleaning in Tank 6F. The largest contributors to radioactivity remaining in Tank 6F (excluding total alpha and total beta) are ${ }^{90} \mathrm{Sr},{ }^{137} \mathrm{Cs},{ }^{241} \mathrm{Am}$, and ${ }^{244} \mathrm{Cm}$.

Table 9 shows the analysis of the free liquid collected from the process sample. The table shows the composition of the Wash Water sample for comparison. Since no material was added to the tank after the Wash Water sample was collected, the composition of the two samples should be the same. The anion concentrations, except for oxalate, are consistent and less than the detection limit. The oxalate concentration in the process sample liquid is approximately one-third the concentration in the Wash Water sample. The same ratio between concentrations is observed in the radionuclides measured by ICPMS. The concentrations of ${ }^{137} \mathrm{Cs},{ }^{239 / 240} \mathrm{Pu},{ }^{241} \mathrm{Am}$, ${ }^{243} \mathrm{Am}$, and ${ }^{244} \mathrm{Cm}$ are higher (by $\sim 2 \mathrm{X}$ ) in the process sample. The concentrations of ${ }^{90} \mathrm{Sr}$ and beta are higher in the wash water sample (by $\sim 2 \mathrm{X}$ ). These differences are larger than the uncertainties in the measurements. We are uncertain of the reason for these differences. 
Table 8. Radionuclide Analysis of Tank 6F Process Sample

\begin{tabular}{|c|c|c|c|c|}
\hline \multirow[b]{2}{*}{ Species } & \multicolumn{2}{|c|}{ Aqua Regia } & \multicolumn{2}{|c|}{ Peroxide Fusion } \\
\hline & $\begin{array}{l}\text { Sample } \\
\mathrm{mCi} / \mathrm{kg}\end{array}$ & $\begin{array}{c}\text { AD Blank } \\
\mathrm{mCi} / \mathrm{kg}\end{array}$ & $\begin{array}{l}\text { Sample } \\
\mathrm{mCi} / \mathrm{kg}\end{array}$ & $\begin{array}{c}\text { AD Blank } \\
\text { mCi/kg }\end{array}$ \\
\hline${ }^{60} \mathrm{Co}$ & $26.4 \pm 0.8$ & $<1.1$ & $17.7 \pm 0.5$ & 0.59 \\
\hline${ }^{90} \mathrm{Sr}$ & $3091 \pm 168$ & $<186$ & $2545 \pm 141$ & $<100$ \\
\hline${ }^{99} \mathrm{Tc}$ & $0.068 \pm 0.003$ & $0.0091 \pm 0.0023$ & $0.033 \pm 0.0015$ & $<0.0033$ \\
\hline${ }^{137} \mathrm{Cs}$ & $81.8 \pm 2.3$ & $<1.18$ & $63.6 \pm 1.8$ & $<0.55$ \\
\hline Alpha & $<450$ & $<20.9$ & $<323$ & $<10.5$ \\
\hline nonvolatile beta & $7700 \pm 450$ & $<45.5$ & $5455 \pm 314$ & $<22.7$ \\
\hline${ }^{239 / 240} \mathrm{Pu}$ & $8.18 \pm 0.26$ & $<0.28$ & $5.45 \pm 0.17$ & $<0.023$ \\
\hline${ }^{238} \mathrm{Pu}$ & $6.36 \pm 0.20$ & $<0.10$ & $4.14 \pm 0.13$ & 0.039 \\
\hline${ }^{241} \mathrm{Am}$ & $159 \pm 7$ & $<0.15$ & $100 \pm 3.1$ & $<0.10$ \\
\hline${ }^{243} \mathrm{Am}$ & $2.5 \pm 0.2$ & $<0.10$ & $1.68 \pm 0.12$ & $0.039 \pm 0.012$ \\
\hline${ }^{242 m} \mathrm{Am}$ & $0.21 \pm 0.04$ & $<0.021$ & $0.18 \pm 0.023$ & $<0.002$ \\
\hline${ }^{243} \mathrm{Cm}$ & $<1.5$ & $<0.73$ & $<0.864$ & $<0.10$ \\
\hline${ }^{245} \mathrm{Cm}$ & $<1.1$ & $<0.59$ & $<0.546$ & $<0.086$ \\
\hline${ }^{247} \mathrm{Cm}$ & $<0.31$ & $<0.24$ & $<0.155$ & $<0.064$ \\
\hline${ }^{249} \mathrm{Cf}$ & $<0.32$ & $<0.25$ & $<0.159$ & $<0.064$ \\
\hline${ }^{251} \mathrm{Cf}$ & $<0.25$ & $<0.21$ & $<0.114$ & $<0.11$ \\
\hline${ }^{242} \mathrm{Cm}$ & $0.18 \pm 0.03$ & $<0.017$ & $0.146 \pm 0.019$ & $<0.0017$ \\
\hline${ }^{244} \mathrm{Cm}$ & $155 \pm 14$ & $0.10 \pm 0.031$ & $2105 \pm 9.1$ & $0.10 \pm 0.017$ \\
\hline${ }^{241} \mathrm{Pu}$ & $16.8 \pm 2.5$ & $<0.041$ & $8.18 \pm 1.18$ & $<0.042$ \\
\hline${ }^{154} \mathrm{Eu}$ & $45.5 \pm 1.3$ & $<1.23$ & $32.3 \pm 0.91$ & $<0.59$ \\
\hline${ }^{155} \mathrm{Eu}$ & $10.5 \pm 0.9$ & $<2.23$ & $8.18 \pm 0.73$ & $<1.14$ \\
\hline${ }^{94} \mathrm{Nb}$ & $<1.5$ & $<0.91$ & $<0.77$ & $<0.45$ \\
\hline${ }^{134} \mathrm{Cs}$ & $<1.5$ & $<1.00$ & $<0.82$ & $<0.50$ \\
\hline
\end{tabular}

\subsection{MASS BALANCE}

SRNL performed a mass balance of the radionuclides and nonradionuclides measured in the cleaning samples and process sample. Equation [2] describes the mass balance.

$$
\begin{aligned}
& \text { initial amount = amount removed }+ \text { amount remaining } \\
& \mathrm{V}_{\mathrm{i}} \mathrm{x}_{\mathrm{i}}=\mathrm{V}_{1} \mathrm{x}_{1}+\mathrm{V}_{2} \mathrm{X}_{2}+\mathrm{V}_{\text {spray }} \mathrm{x}_{\text {spray }}+\mathrm{V}_{\text {water }} \mathrm{X}_{\text {water }}+\mathrm{V}_{\text {proc-sol }} \mathrm{X}_{\text {proc-sol }}+\mathrm{V}_{\text {proc-liq }} \mathrm{x}_{\text {proc-liq }}
\end{aligned}
$$

where $V_{i}$ is the initial volume of sludge in the tank, $x_{i}$ is the initial concentration of the component in the sludge, $\mathrm{V}_{1}$ is the volume of material removed from the tank following Acid Strike $1, \mathrm{x}_{1}$ is the concentration in the liquid sample following Strike $1, \mathrm{~V}_{2}$ is the volume of material removed from the tank following Acid Strike 2, $\mathrm{x}_{2}$ is the concentration in the liquid sample following Strike 2, $\mathrm{V}_{\text {spray }}$ is the volume of material removed from the tank following the Spray Wash, $\mathrm{x}_{\text {spray }}$ is the concentration in the liquid sample following the Spray Wash, $\mathrm{V}_{\text {water }}$ is the volume of material removed from the tank following the Water Wash, $\mathrm{x}_{\text {water }}$ is the concentration in the liquid sample following the Water Wash, $\mathrm{V}_{\text {proc-sol }}$ is the volume of sludge remaining in the tank following the Water Wash, $\mathrm{x}_{\text {proc-sol }}$ is the concentration in the sludge process sample, $\mathrm{V}_{\text {proc-liq }}$ is the volume of liquid remaining in the tank following the Water Wash, and $\mathrm{x}_{\text {proc-liq }}$ is the concentration in the liquid remaining in the tank following the Water Wash (assumed equal to the concentration in the Water Wash sample where analyses were not performed). The initial concentration of the component in the sludge $\left(\mathrm{x}_{\mathrm{i}}\right)$ is unknown. Equation 
[2] can be solved to determine $\mathrm{x}_{\mathrm{i}}$. Table 10 shows the volumes of sludge and liquid used to perform the mass balance.

Table 9. Analysis of Free Liquid Collected from Process Sample

Species

$\mathrm{F}$

formate

$\mathrm{Cl}$

NO2

NO3

$\mathrm{PO} 4$

$\mathrm{SO} 4$

Oxalate

$\mathrm{Hg}$

$\mathrm{Br}$

${ }^{235} \mathrm{U}$

${ }^{237} \mathrm{~Np}$

${ }^{238} \mathrm{U}$

${ }^{239} \mathrm{Pu}$

${ }^{234} \mathrm{U}$

${ }^{90} \mathrm{Sr}$

${ }^{99} \mathrm{Tc}$

${ }^{137} \mathrm{Cs}$

Alpha

nonvolatile beta

${ }^{239 / 240} \mathrm{Pu}$

${ }^{238} \mathrm{Pu}$

${ }^{241} \mathrm{Am}$

${ }^{243} \mathrm{Am}$

${ }^{242 \mathrm{~m}} \mathrm{Am}$

${ }^{243} \mathrm{Cm}$

${ }^{245} \mathrm{Cm}$

${ }^{247} \mathrm{Cm}$

${ }^{249} \mathrm{Cf}$

${ }^{251} \mathrm{Cf}$

${ }^{242} \mathrm{Cm}$

${ }^{244} \mathrm{Cm}$

${ }^{241} \mathrm{Pu}$

n.m. not measured
Tank 6F Process Sample Tank 6F Water Wash Sample

$\underline{\text { Ratio }}$

$(\mathrm{mg} / \mathrm{L})$

$<466$

$(\mathrm{mg} / \mathrm{L})$

$<334$

$<334$

$<334$

$<334$

$<334$

$<334$

$<334$

1884

596

$2.33 \pm 0.47$

$<466$

$1.1 \pm 0.22$

$0.1 \pm 0.02$

$248.0 \pm 50$

$<0.075$

$<0.075$

$(\mathrm{dpm} / \mathrm{mL})$

$1.1 \times 10^{7} \pm 1.2 \times 10^{6}$

$<2.2 \times 10^{2}$

$7.0 \times 10^{6} \pm 3.5 \times 10^{5}$

$<2.7 \times 10^{6}$

$3.5 \times 10^{7} \pm 3.5 \times 10^{6}$

$7.3 \times 10^{3} \pm 2.6 \times 10^{3}$

$<1.6 \times 10^{3}$

$1.3 \times 10^{4} \pm 2.0 \times 10^{3}$

$3.8 \times 10^{3} \pm 6.8 \times 10^{2}$

$<1.8 \times 10^{1}$

$<3.0 \times 10^{3}$

$<2.4 \times 10^{3}$

$<4.7 \times 10^{3}$

$<4.4 \times 10^{3}$

$<2.2 \times 10^{3}$

$<1.5 \times 10^{1}$

$1.1 \times 10^{4} \pm 2.8 \times 10^{3}$

$<1.6 \times 10^{4}$ n.m.

$<334$

$3.56 \pm 0.71 \quad 0.31$

$<0.406$

$905 \pm 180$

$<0.676$

n.m.

(dpm/mL)

$\begin{aligned} & 2.1 \times 10^{7} \pm 4.1 \times 10^{4} \\ < & 4.2 \times 10^{2} \\ & 4.3 \times 10^{6} \pm 2.2 \times 10^{3}\end{aligned}$

$<3.3 \times 10^{5}$

$6.3 \times 10^{7} \pm 6.3 \times 10^{4} \quad 0.56$

$3.5 \times 10^{3} \pm 1.8 \times 10^{2} \quad 2.09$

$2.7 \times 10^{3} \pm 1.5 \times 10^{2} \quad<0.59$

$5.6 \times 10^{3} \pm 9.4 \times 10^{2} \quad 2.32$

$<84.7 \quad>45$

$<18.0$

$<3.1 \times 10^{2}$

$<3.1 \times 10^{2}$

$<3.5 \times 10^{2}$

$<2.3 \times 10^{2}$

$<14.9$

$9.5 \times 10^{2} \pm 2.7 \times 10^{2}$

n.m.
0.32

0.27

11.6
$<2.5 \times 10^{2}$

Table 10. Volumes of Sludge and Liquid in Tank 6F during Chemical Cleaning

$\mathrm{V}_{1}$

$\mathrm{V}_{2}$

$\mathrm{V}_{\text {spray }}$

$\mathrm{V}_{\text {water }}$

$\mathrm{V}_{\text {proc-sol }}$

$\mathrm{V}_{\text {proc-liq }}$

439,000 L

$122,000 \mathrm{~L}$

$85,500 \mathrm{~L}$

427,000 L

$13,000 \mathrm{~L}$

$30,772 \mathrm{~L}$

Table 11 shows the amount of each component removed during the acid strikes and washes, as well as the amount remaining in the sludge and liquid. The data show a significant decrease (> 90\%) in the amount of ${ }^{90} \mathrm{Sr}$ and ${ }^{137} \mathrm{Cs}$ removed during Strike 2, the Spray Wash, and the Water 
Wash compared to Strike 1. The data show less of a decrease for plutonium. Comparing the amount of iron removed with the amount expected to be released from corrosion $(85 \mathrm{~kg}$, see equation [1]) shows most of the iron in the samples following Strike 1 is from sludge dissolution rather than corrosion. The iron in the Strike 2, Spray Wash, and the Water Wash samples is of the same order as the amount expected from oxalic acid corrosion. The table also shows most of the activity remaining in the tank is in the sludge rather than in the liquid.

Table 11. Amount of Material Removed from Tank 6F

Species

$\mathrm{Al}$
$\mathrm{Ba}$
$\mathrm{Ca}$
$\mathrm{Cr}$
$\mathrm{Fe}$
$\mathrm{Li}$
$\mathrm{Mg}$
$\mathrm{Mn}$
$\mathrm{Na}$
$\mathrm{Ni}$
$\mathrm{Si}$
$\mathrm{Sr}$
$\mathrm{U}$
$\mathrm{Zr}$
$\mathrm{Hg}$
$\mathrm{Sum}$

${ }^{234} \mathrm{U}$

${ }^{235} \mathrm{U}$

${ }^{237} \mathrm{~Np}$

${ }^{239} \mathrm{U}$

${ }^{60} \mathrm{Co}$

${ }^{90} \mathrm{Sr}$

${ }^{99} \mathrm{Tc}$

${ }^{137} \mathrm{Cs}$

Alpha

Beta

${ }^{239 / 240} \mathrm{Pu}$

${ }^{238} \mathrm{Pu}$

${ }^{241} \mathrm{Am}$

${ }^{243} \mathrm{Am}$

${ }^{242 \mathrm{~m}} \mathrm{Am}$

${ }^{243} \mathrm{Cm}$

${ }^{245} \mathrm{Cm}$

${ }^{247} \mathrm{Cm}$

${ }^{249} \mathrm{Cf}$

${ }^{251} \mathrm{Cf}$

${ }^{242} \mathrm{Cm}$

${ }^{244} \mathrm{Cm}$

${ }^{241} \mathrm{Pu}$

${ }^{154} \mathrm{Eu}$

${ }^{155} \mathrm{Eu}$

Sum
Strike 1

(kg)

452

4.8

119

7.2

5153

29.6

14.8

260

1315

21.5

119

14.8

2164

88

n.
9760

9.2
0.5

2100

0.4

(dpm)

$1.0 \times 10^{18}$

$2.4 \times 10^{16}$

$7.7 \times 10^{17}$

$6.2 \times 10^{13}$

$4.8 \times 10^{13}$

$5.3 \times 10^{14}$

$9.1 \times 10^{12}$

$9.1 \mathrm{x} 10^{11}$

$7.7 \times 10^{11}$

$5.3 \times 10^{14}$

$1.8 \times 10^{18}$
Strike 2

(kg)

22.8

0.6

7.2

0.5
299

2.0

1.1

12.2

112

0.9

5.0

0.7

150

3.3

n.m.

618

0.7

138

(dpm)

$6.9 \times 10^{16}$

$2.5 \times 10^{10}$

$1.9 \times 10^{15}$

$5.6 \times 10^{14}$

$1.4 \times 10^{17}$

$2.2 \times 10^{12}$

$1.3 \times 10^{12}$

Spray wash

(kg)

1.13

0.21

0.03

18.4

0.07

0.06

0.54

5.17

0.04

0.17

0.03

9.17

0.15

n.m.

35.2

44.5

8.74

(dpm)

$2.8 \times 10^{16}$

$3.4 \times 10^{10}$

$8.4 \times 10^{14}$

$4.6 \times 10^{13}$

$5.8 \times 10^{16}$

$1.3 \times 10^{12}$

$9.5 \times 10^{11}$

$1.2 \times 10^{12}$
$2.4 \times 10^{12}$

$1.2 \times 10^{12}$
$2.4 \times 10^{12}$

(dpm)

$8.7 \times 10^{15}$

$1.8 \times 10^{15}$

$2.7 \times 10^{16}$

$1.5 \times 10^{12}$

(2)

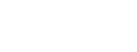

(2n)

$6.1 \times 10^{11}$

$2.1 \times 10^{17}$

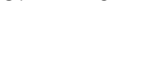

$8.8 \times 10^{16}$
$4.1 \times 10^{11}$

$3.8 \times 10^{16}$

$\begin{array}{cc}\text { Remaining } & \text { Remaining } \\ \text { Solid } & \text { Liquid } \\ (\mathrm{kg}) & (\mathrm{kg})\end{array}$

21.1

13.3

4.5

1898.2

6.5

6.6

266.6

24.1

1219.0

16.3

0.8

32.9

10.2

93

3661.1

$<0.1$

0.2

0.2

58.6

1.6

(dpm)

$1.3 \times 10^{15}$

$1.6 \times 10^{17}$

$2.9 \times 10^{12}$

$4.1 \times 10^{15}$

$2.3 \times 10^{16}$

$3.8 \times 10^{17}$

$3.9 \times 10^{14}$

$3.0 \times 10^{14}$

$7.5 \times 10^{15}$

$1.2 \times 10^{14}$

$1.1 \times 10^{13}$

$6.9 \times 10^{13}$

$4.8 \times 10^{13}$

$1.3 \times 10^{13}$

$1.4 \times 10^{13}$

$1.0 \times 10^{13}$

$9.4 \times 10^{12}$

$7.5 \times 10^{15}$

$7.2 \times 10^{14}$

$2.3 \times 10^{15}$

$5.4 \times 10^{14}$

$6.0 \times 10^{17}$

0.2

n.d.

0.05

n.d.

2.2

n.d.

0.02

0.3

6.6

n.d.

0.4

n.d.

9.1

0.02

n.m.

18.8

$<0.001$

0.01

0.001

2.5

$<0.001$

(dpm)

$1.2 \times 10^{14}$

$2.2 \times 10^{9}$

$7.2 \times 10^{13}$

$2.8 \times 10^{13}$

$3.6 \times 10^{14}$

$3.6 \times 10^{10}$

$1.6 \times 10^{10}$

$7.2 \times 10^{10}$

$1.5 \times 10^{11}$

$6.5 \times 10^{14}$ 
Table 12 shows the fraction of each species removed from Tank 6F and the amount remaining in the tank following chemical cleaning. The table shows more than $90 \%$ of the aluminum, calcium, sodium, and uranium has been removed from the tank. The fraction of lithium, chromium, iron, magnesium, manganese, silicon, and zirconium removed was $50-90 \%$. The fraction of barium removed was $20 \%$. Only $2 \%$ of the nickel was removed. Table 12 shows a difference in the removal of cold strontium (95\%) compared to ${ }^{90} \mathrm{Sr}(87 \%)$. This difference is due to analytical uncertainty.

\section{Table 12. Fraction Removed and Amount Remaining in Tank 6F}

\section{Species}

Al

$\mathrm{Ba}$

$\mathrm{Ca}$

$\mathrm{Cr}$

$\mathrm{Fe}$

$\mathrm{Li}$

$\mathrm{Mg}$

Mn

$\mathrm{Na}$

$\mathrm{Ni}$

Si

$\mathrm{Sr}$

U

$\mathrm{Zr}$

$\mathrm{Hg}$

${ }^{234} \mathrm{U}$

${ }^{235} \mathrm{U}$

${ }^{237} \mathrm{~Np}$

${ }^{238} \mathrm{U}$

${ }^{239} \mathrm{Pu}$

${ }^{60} \mathrm{Co}$

${ }^{90} \mathrm{Sr}$

${ }^{99} \mathrm{TC}$

${ }^{137} \mathrm{Cs}$

Alpha

Beta

${ }^{239 / 240} \mathrm{Pu}$

${ }^{238} \mathrm{Pu}$

${ }^{241} \mathrm{Am}$

${ }^{243} \mathrm{Am}$

${ }^{242 \mathrm{~m}} \mathrm{Am}$

${ }^{243} \mathrm{Cm}$

${ }^{245} \mathrm{Cm}$

${ }^{247} \mathrm{Cm}$

${ }^{249} \mathrm{Cf}$

${ }^{251} \mathrm{Cf}$

${ }^{242} \mathrm{Cm}$

${ }^{244} \mathrm{Cm}$

${ }^{241} \mathrm{Pu}$

${ }^{154} \mathrm{Eu}$

${ }^{155} \mathrm{Eu}$
Fraction Removed

(\%)

$91.0 \%$

$20.3 \%$

$90.6 \%$

$63.4 \%$

$74.5 \%$

$83.0 \%$

$71.8 \%$

$51.5 \%$

$98.2 \%$

$1.8 \%$

$89.4 \%$

$94.9 \%$

$98.5 \%$

$90.1 \%$

n.m.

(\%)

$99.6 \%$

$73.0 \%$

$97.7 \%$

$19.2 \%$

$\mathrm{b}$

$87.2 \%$

$2.0 \%$

$87.2 \%$

$2.5 \%$

$72.1 \%$

$14.6 \%$

$14.5 \%$

$6.6 \%$

$6.9 \%$

$7.1 \%$

n.m.

n.m.

n.m.

n.m.

n.m.

n.m.

$7.5 \%$

$6.5 \%$

n.m.

n.m.
Amount Remaining

$\begin{aligned} \text { (kg) } & \\ 48 & \text { n.m. not measured } \\ 21 & \text { a all samples less } \\ 13 & \text { than detection limit - } \\ 4 & \text { fraction removed should } \\ 1900 & \text { be the same as other } \\ 7 & \text { isotopes } \\ 7 & \text { ball samples less than } \\ 267 & \text { detection limit }\end{aligned}$

31

1219

17

1

42

10

93

(Ci)

$<0.1$

0.001

0.137

0.021

100.2

577

74, 147

1,905

10,518

174,986

178

138

3,421

56

5

31

22

6

6

5

4

3,421

327

1,023

243 
Most of the mass remaining in the tank is iron and nickel. The remaining sludge contains $21 \mathrm{~kg}$ of barium, $4 \mathrm{~kg}$ of chromium, and $93 \mathrm{~kg}$ of mercury. If the Tank $6 \mathrm{~F}$ liquid samples contained $2.33 \mathrm{mg} / \mathrm{L}$ of mercury (as measured in the Tank 6F process sample liquid), the amount of mercury dissolved and removed in the oxalic acid strikes, Spray Wash, and Water Wash (1,000,000 L total volume), would be $2.36 \mathrm{~kg}$ (2.6\%).

The chemical cleaning removed more than $90 \%$ of the uranium isotopes. It removed $\sim 73 \%$ of the ${ }^{237} \mathrm{~Np}, \sim 87 \%$ of the ${ }^{90} \mathrm{Sr}$, and $\sim 87 \%$ of the ${ }^{137} \mathrm{Cs}$. The cleaning removed $\sim 2 \%$ of the technetium. The chemical cleaning removed less than $15 \%$ of the plutonium, americium, and curium isotopes. ${ }^{\text {ii }}$ The chemical cleaning removed a larger fraction of the plutonium, americium, and curium in than in Tank 5F. This improved removal could be from the lower $\mathrm{pH}$ in Tank 6F following Strike 1 or to the plutonium, americium, and curium being present in different compounds in Tank 6F. Most of the activity remaining in the tank is from beta-emitters and ${ }^{90} \mathrm{Sr}$.

\subsection{COMPARISON WITH CHEMICAL CLEANING DEMONSTRATIONS}

Table 13 shows the fraction of select species dissolved during the first oxalic acid strike in Tank 6F and compares it with the results from the SRNL demonstrations with Tank 5F samples or simulated waste. ${ }^{12,6}$ (No Tank 6F was obtained prior to mechanical cleaning and no separate laboratory demonstrations were performed for that tank waste. Hence, the only comparison available is with the demonstrations for Tank 5F.) In general, there is good agreement between the chemical cleaning in Tank 6F and the demonstrations. The iron dissolved in Tank 6F shows better agreement with the demonstration results than samples from Tank $5 \mathrm{~F}^{5}$ The likely reason for the improved agreement is the $\mathrm{pH}$ following the first acid addition (i.e., $\mathrm{pH} 2$ in Tank 6F versus $\mathrm{pH} 4$ in Tank 5F). Another plausible explanation is different iron compounds in Tank 6F. The plutonium removal is better in Tank 6F than in the demonstration.

\begin{tabular}{|c|c|c|c|}
\hline Species & Tank 6F & Actual Waste Demonstration $^{6}$ & Simulant Demonstration $^{12}$ \\
\hline $\mathrm{Fe}$ & $69 \%$ & $62 \%$ & $99 \%$ \\
\hline $\mathrm{U}$ & $79 \%$ & $73 \%$ & $100 \%$ \\
\hline Mn & $47 \%$ & $40 \%$ & $43 \%$ \\
\hline $\mathrm{Ni}$ & $1.7 \%$ & $0.1 \%$ & n.m. \\
\hline $\mathrm{Na}$ & $75 \%$ & $96 \%$ & $96 \%$ \\
\hline $\mathrm{Al}$ & $85 \%$ & $84 \%$ & n.m. \\
\hline${ }^{238} \mathrm{Pu}$ & $13 \%$ & $2.9 \%$ & n.m. \\
\hline${ }^{239 / 240} \mathrm{Pu}$ & $14 \%$ & $3.2 \%$ & n.m. \\
\hline
\end{tabular}

In comparing the results from chemical cleaning with the results from the demonstrations, one assumes that the iron is present as the same compounds in both. If the iron is present as different compounds in Tank 6F than in the demonstrations, the dissolution rate and fraction dissolved could be significantly different. ${ }^{13}$ The iron in the simulant demonstration was added as ferric hydroxide $\left(\mathrm{Fe}(\mathrm{OH})_{3}\right) .{ }^{12}$ The iron in the actual waste demonstration (with Tank 5F sludge) and

\footnotetext{
ii Plutonium removal based on PUTTA analysis rather than ICPMS analysis. PUTTA more accurate and had lower uncertainty.
} 
Tank 6F likely contained a variety of iron compounds. SRNL analysis of Tank Farm sludge samples shows the iron to be primarily magnetite $\left(\mathrm{Fe}_{3} \mathrm{O}_{4}\right)$ and hematite $\left(\mathrm{Fe}_{2} \mathrm{O}_{3}\right)$. Larsen and Postma investigated the dissolution of iron oxide compounds and found the dissolution rates to vary as much as two orders of magnitude between different iron compounds. ${ }^{14}$ Torres et al. investigated the dissolution of hematite and magnetite by oxalic acid and found magnetite to dissolve more readily than hematite with oxalic acid. ${ }^{15}$ Lee et al investigated the dissolution of iron oxide by oxalic acid and found that goethite $(\mathrm{FeOOH})$ and lepidocrosite $(\mathrm{FeOOH})$ dissolve more rapidly that hematite. ${ }^{16}$ Taxiarchou et al. investigated the dissolution of hematite in oxalic acid solutions and found the dissolution to occur faster under visible light. ${ }^{17}$ The sludge in the demonstrations was exposed to visible light, while the sludge in Tank $6 \mathrm{~F}$ was not. Therefore, if Tank 6F sludge contained iron in the form of hematite, then this would explain the reduction in the fraction of iron removed when compared to the simulant demonstration.

The mixing in the simulant demonstration differed from the mixing in Tank 6F. In the simulant demonstration, the mixing started $\sim 2$ days after oxalic acid addition began. Reviewing the data from Test 2 and Test 3 shows a significant increase in the amount of iron and manganese dissolved after the mixing started. ${ }^{12}$ The mixing improves contact between the acid and sludge and increases the mass transfer rate. Both effects should increase the sludge dissolution rate. Mixing in Tank 6F will also improve the suspension of solid particles that are not dissolved by the oxalic acid.

Performing a sludge wash prior to oxalic acid addition will reduce the ionic strength of the liquid in the tank, which will increase the oxalate solubility. In addition, the washing will reduce the total base in the tank and help ensure the $\mathrm{pH}$ is less than 2 after acid addition.

Oxalic acid effectively removed uranium from Tank $5 \mathrm{~F}$, and removed $\sim 70 \%$ of the ${ }^{237} \mathrm{~Np}$ from the tank.

The oxalic acid was not effective at removing the ${ }^{99}$ Tc from the tank. This result is different from Tank 5F, where the acid was effective at removing technetium. The difference could be due to different technetium compounds in the two tanks or to the sludge heel not being homogeneous in one or both of the tanks.

The oxalic acid was not effective at removing plutonium, americium, and nickel from the sludge heel. It was marginally effective at removing manganese. Since mercury was not measured in the liquid samples collected following the oxalic acid strikes, spray wash, and water wash, we cannot assess the effectiveness of oxalic acid at removing mercury. However, comparing the mercury concentration in the liquid process sample with its concentration in the solid process sample suggests that the oxalic acid was not effective in removing mercury.

SRNL did not measure the ${ }^{14} \mathrm{C}$ in the process sample.

If more ${ }^{239} \mathrm{Pu},{ }^{241} \mathrm{Am},{ }^{99} \mathrm{Tc}, \mathrm{Hg}, \mathrm{Mn}$, or Ni needs to be removed from the tank, a cleaning agent other than oxalic acid needs to be selected. Nitric acid is a plausible acid to dissolve ${ }^{239} \mathrm{Pu}$, ${ }^{241} \mathrm{Am},{ }^{99} \mathrm{Tc}, \mathrm{Hg}, \mathrm{Mn}$, and Ni, but it readily corrodes carbon steel. Sodium carbonate is a plausible chemical to dissolve the plutonium and americium. 
When performing chemical cleaning on other waste tanks, ensure the $\mathrm{pH}$ of the acid is less than 2 before removing the acid from the tank. Prior to performing chemical cleaning, collect a sludge sample and analyze it for key contaminants to better evaluate the efficiency of chemical cleaning.

\subsection{CONCLUSIONS}

The conclusions from this work are as follows.

- The dissolution of sludge components in Tank 6F agreed well with the expected behavior as projected from the 2007 actual waste demonstration for Tank 5F. The iron removal from Tank $6 \mathrm{~F}$ (70\%) agrees better with the demonstration results (62\%) than the iron removal from Tank 5F (30\%).

- The chemical cleaning removed more than $95 \%$ of the uranium isotopes.

- The chemical cleaning removed $\sim 73 \%$ of the neptunium, $\sim 87 \%$ of the ${ }^{90} \mathrm{Sr}$, and $\sim 87 \%$ of the ${ }^{137} \mathrm{Cs}$.

- The chemical cleaning removed less than $15 \%$ of the technetium, plutonium, americium, and curium isotopes.

- Most of the activity remaining in the tank is from beta emitters and ${ }^{90} \mathrm{Sr}$.

- The chemical cleaning removed more than $90 \%$ of the aluminum, calcium, sodium, and uranium from the tank.

- The fraction of chromium, iron, lithium, magnesium, manganese, silicon, and zirconium removed was $50-90 \%$.

- The fraction of barium removed was $20 \%$.

- Only $2 \%$ of the nickel was removed.

- Most of the mass remaining in the tank is iron and nickel.

- The remaining sludge contains $\sim 21 \mathrm{~kg}$ of barium, $\sim 4 \mathrm{~kg}$ of chromium, and $\sim 93 \mathrm{~kg}$ of mercury.

- Chemical cleaning in Tank 6F showed better removal of iron, plutonium, americium, and curium than in Tank 5F. The likely causes of the better removal is the lower $\mathrm{pH}$ following Acid Strike 1 and different chemical compounds in Tank 6F than in Tank 5F.

SRNL makes the following recommendations to remove the remaining sludge and activity in Tank 6F and to improve sludge heel removal in other tanks.

- When performing chemical cleaning on future waste tanks, ensure the $\mathrm{pH}$ of the acid is less than 2 before removing the acid from the tank. The lower $\mathrm{pH}$ will increase iron solubility.

- Prior to performing chemical cleaning for future tanks, collect a sludge sample and have it analyzed for key contaminants. This provides a baseline for comparison, which allows a better evaluation of the efficiency of future chemical cleaning activities.

- Future work should include analysis of the solid samples by a method such as X-ray diffraction (XRD) to identify the specific compounds of the key contaminants.

- Mix the tank as soon as it contains sufficient liquid. The mixing will promote contact between the acid and sludge, improving the dissolution rate. The mixing will also suspend particles not dissolved by the acid. 
- The sludge heel should be washed to reduce the liquid ionic strength prior to starting chemical cleaning. Reducing the ionic strength will increase the oxalate solubility.

\subsection{REFERENCES}

\footnotetext{
${ }^{1}$ G. D. Thaxton and W. J. Vetsch, “Tank 6 First Acid Strike Chemical Cleaning Report”, LWO-LWE-2008-00228, August 12, 2006.

${ }^{2}$ M. R. Poirier, “Analysis of Samples from Chemical Cleaning in Tank 6F”, SRNLL3100-2008-00021, Rev. 2, June 29, 2009.

${ }^{3}$ G. D. Thaxton and W. J. Vetsch, “Tank 6 Second Acid Strike Chemical Cleaning Report”, LWO-LWE-200800284, September 9, 2008.

${ }^{4}$ G. D. Thaxton and W. J. Vetsch, "Tank 6 Acid and Deionized Water Spray Wash and Final Water Wash Report”, LWO-LWE-2008-00393, June 4, 2009.

${ }^{5}$ D. T. Herman, B. J. Wiersma, F. F. Fondeur, J. C. Wittkop, J. M. Pareizs, K. P. Crapse, M. S. Hay, M. R. Poirier and S. D. Fink, "Investigating Hydrogen Generation and Corrosion in the Treatment Tank and Potential Formation of a Floating Layer in Neutralizing Tank during Waste Tank Heel Chemical Cleaning,” WSRC-STI-2007-00209, April 30, 2007.

${ }^{6}$ M. S. Hay, K. P. Crapse, S. D. Fink, and J. M. Pareizs, "Characterization and Actual Waste Tests with Tank 5F Samples," WSRC-STI-2007-00192, Washington Savannah River Company (2007).

${ }^{7}$ M. R. Poirier and S. D. Fink, “Analysis of Samples from Tank 5F Chemical Cleaning”, SRNL-STI-2009-00492, August 2009.

${ }^{8}$ J. J. Phillips, “Carbon Steel Components in Type I and Type II Tanks and Annuli”, C-CLC-G-00355, Rev. 0, July 30, 2004.

${ }^{9}$ R. H. Perry and C. H. Chilton, Eds., Chemical Engineers' Handbook, $5^{\text {th }}$ Ed., McGraw-Hill, New York, 1973.

${ }^{10}$ M. E. Garcia-Clavel, M. J. Martinez-Lope, and M. T. Casais-Alvarez, "Thermal Study of $\mathrm{NiC}_{2} \mathrm{O}_{4} * \mathrm{H}_{2} \mathrm{O} \mathrm{Obtained}$ by a Solid State Reaction at Room Temperature and Normal Pressure”, Thermochimica Acta, vol. 118, pp. 123-134, 1987.

${ }^{11}$ M. R. Poirier and S. D. Fink, “Analysis of Solids Remaining Following Chemical Cleaning in Tank 6F”, SRNLSTI-2009-00816, December 21, 2009.

${ }^{12}$ D. T. Herman, B. J. Wiersma, F. F. Fondeur, J. C. Wittkop, J. M. Pareizs, K. P. Crapse, M. S. Hay, M. R. Poirier and S. D. Fink, "Investigating Hydrogen Generation and Corrosion in the Treatment Tank and Potential Formation of a Floating Layer in Neutralizing Tank during Waste Tank Heel Chemical Cleaning,” WSRC-STI-2007-00209, April 30, 2007.

${ }^{13}$ S. O. Lee, T. Tran, B. H. Jung, S. J. Kim, and M. J. Kim, “Dissolution of Iron Oxide using Oxalic Acid”, Hydrometallurgy, vol. 87, 2007, pp. 91-99.

${ }^{14}$ O. Larsen and D. Postma, "Kinetics of Reductive Bulk Dissolution of Lepidocrocite, Ferrihydrite, and Goethite”, Geochimica et Cosmochimica Acta, vol. 65, No. 9, pp. 1367-1379, 2001.

${ }^{15}$ R. Torres, M. A. Blesa, and E. Matijevic, "Interactions of Metal Hydrous Oxides with Chelating Agents: IX. Reductive Dissolution of Hematite and Magnatite by Aminocarboxylic Acids”, J. Colloid Interface Sci., vol. 134, No. 2, pp. 475-485, 1990.

${ }^{16}$ S. O. Lee, T. Tran, B. H. Jung, S. J. Kim, and M. J. Kim, “Dissolution of Iron Oxide using Oxalic Acid”, Hydrometallurgy, vol. 87, Issue 3-4, pp. 91-99, 2007.

${ }^{17}$ M. Taxiarchou, D. Panias, I. Douni, I. Paspaliaris, and A. Kontopoulos, "Dissolution of Hematite in Acidic Oxalate Solutions”, Hydrometallurgy, vol. 44, Issue 3, pp. 287-299, 1997.
} 